\title{
Phytoremediation: A Sustainable Approach for Restoration of Metal Contaminated Sites
}

\author{
Shikha Singh ${ }^{1}$, Anita Singh ${ }^{2}$ \\ Ranjan Plant Physiology and Biochemistry Laboratory, Department of Botany, University of Allahabad, Allahabad-211002, India
}

\begin{abstract}
Heavy metal pollution is one of the major ecological concerns worldwide which pose threat to plants as well as animals. Heavy metals are highly toxic, often non-biodegradable and may reduce the growth of microbial communities present in soil, thereby retard the bioremediation processes. These toxic metals are readily taken up by plants from soil and water through roots, and increase in heavy metal concentration causes phytotoxic effects i.e. growth, physiological, biochemical and molecular processes in plants. Therefore, phytoremediation is a sustainable approach for the clean-up of metal contaminated sites. Phytoremediation, the technology involved use of plants to remediate to sites contaminated with organic and inorganic pollutants as well as pollutants removed for commercial purposes.
\end{abstract}

Keywords: contaminated, heavy metal, toxicity, pollution, phytoremediation

\section{Introduction}

Rapid industrialization and urbanization around the world have led to the pollution of environment with various toxic and hazardous materials that are the major challenges of $21^{\text {st }}$ century. Heavy metal pollution is one of the major ecological concerns due to its direct impact on plant productivity. Large areas of the world have been contaminated with organic and inorganic pollutants. Organic pollutants are mostly anthropogenic in origin and are released into the environment via solvent and fuel spills, military operations, agricultural practices, and industrial activities. Inorganic pollutants, on the other hand, occur as natural elements in the Earth's crust. Inorganic pollutants can be plant macronutrients such as nitrates and phosphates, micronutrients such as chromium $(\mathrm{Cr})$, copper $(\mathrm{Cu})$, iron $(\mathrm{Fe})$, manganese $(\mathrm{Mn})$, molybdenum (Mo), nickel (Ni), zinc $(\mathrm{Zn})$, nonessential elements such as arsenic (As), cadmium $(\mathrm{Cd})$, cobalt $(\mathrm{Co})$, mercury $(\mathrm{Hg})$, lead $(\mathrm{Pb})$, vanadium $(\mathrm{V})$ etc. and radionuclides such as $238 \mathrm{U}, 137 \mathrm{Cs}$, and $90 \mathrm{Sr}[1,2]$. Environmental contamination by pollutants whether organic or inorganic, directly or indirectly affects the human health, productivity of agricultural lands, and also the stability of natural environment [3]. Extensive contamination of agricultural lands has significantly decreased the extent of arable land available for cultivation worldwide. Hence the present scenario on the worldwide problems of environmental pollution demands immediate attention towards the remediation and detoxification of these toxic and hazardous pollutants in order to have clean, green and safe environment. Therefore, the sincere efforts have been made to search the less polluting and cost effective environment friendly technologies. In this regard in recent years, the phytoremediation technology being as an effective and low cost alternative to conventional remediation technologies has gained much more attention towards the clean-up of environment polluted by a broad range of toxic and harmful materials.

Phytoremediation is an eco-sustainable and cost effective green strategy for the conventional clean-up technologies that often needs high investments, huge energy expenditure and much labour. It could be considered as a long-term process that can be easily applied around the tannery complex and contaminated sites. It is also an in situ remediation technology that uses the inherent potentials of plants to remove the toxic heavy metals such as $\mathrm{Cd}, \mathrm{Cr}, \mathrm{Ni}$, $\mathrm{Hg}$ and As etc. from contaminated soils [5-7]. In developing countries, treated and untreated waste water is commonly used for the irrigation of agricultural land. Long-term irrigation results into the accumulation of metals and that change the quality of soil. Therefore, remediation of heavy metals from the contaminated sites by using green technology is a suitable approach [8].

The natural/geological and anthropogenic activities are the major sources of heavy metal pollution. Heavy metals are easily taken up by the plants through their roots and transported to other aerial parts. Uptake of these metals depends on several factors such as soil $\mathrm{pH}$, temperature, organic contents, presence of chelating agents etc. Among various soil factors, soil $\mathrm{pH}$ being the most important factor to affect the availability of heavy metals. The success of metal remediation process depends on those plants which can accumulates desired levels of metal concentration in their aerial parts (100-1000 folds) without any visible symptoms and these plants are termed as hyperaccumulators and the phenomenon is termed as hyperaccumulation. About 500 plant species have metal hyperaccumulation characteristic, among these approximately $0.2 \%$ belong to angiosperm [9]. The ideal plants for phytoremediation should have the ability to accumulate high metal content, tolerate high salt concentration, having fast growth rate, higher biomass production, easily harvestable and must translocate metals to their above ground parts efficiently [6]. For selecting model plant species for phytoremediation, the ratio of metals between soil and plant parts (metal transfer factor) is measured and this ratio should be more than one. It means higher accumulation of metals in plant parts than soil [10]. Gupta et al. [11] have been studied the multiple metal accumulation characteristics of three wild macrophyte species viz., Ipomea sp., Eclipta sp. and Marsilea sp. and recorded that Ipomea sp. For $\mathrm{Cd}, \mathrm{Cu}, \mathrm{Mn}$ and $\mathrm{Zn}$, while Eclipta sp. and Marsilea sp. shows transfer factor more than one for $\mathrm{Fe}, \mathrm{Cu}$ and $\mathrm{Cd}$. Uptake of metals depends on the type and chemical speciation of metal and habitat characteristics 


\section{International Journal of Science and Research (IJSR) \\ ISSN (Online): 2319-7064}

Index Copernicus Value (2013): 6.14 | Impact Factor (2014): 5.611

of plants, i.e., terrestrial, aquatic etc. Therefore, plant selection is important for remediation of contaminated site. The plants having the remediation property belong to different families such as Asteraceae, Brassicaceae, Caryophyllaceae, Cyperaceae, Cunouniaceae, Fabaceae, Flacourtiaceae, Lamiaceae, Poaceae, Violaceae, and Euphorbiaceae [9]. Many plant species, which are reported as hyperaccumulators based on their capacity to tolerate toxic metal concentration, are summarized in Table 1.

Table 1: Some metal hyperaccumulator plant species

\begin{tabular}{|l|l|c|c|}
\hline \multicolumn{1}{|c|}{ Plant species } & \multicolumn{1}{|c|}{ Family } & Metals & Reference \\
\hline Alyssum lesbiacum & Brassicaceae & $\mathrm{Ni}$ & {$[12]$} \\
\hline Arabidopsis thalliana & Brassicaceae & $\mathrm{As}$ & {$[13]$} \\
\hline Andrographis paniculata & Acanthaceae & $\mathrm{Cd}, \mathrm{Pb}, \mathrm{Zn}$ & {$[14]$} \\
\hline Brassica napus & Brassicaceae & $\mathrm{Cd}$ & {$[15]$} \\
\hline Calotropis pocera & Asclepediaceae & $\mathrm{Cd}, \mathrm{Pb}$ & {$[16]$} \\
\hline Eclipta & Asteraceae & $\mathrm{Fe}, \mathrm{Cd}, \mathrm{Cu}$ & {$[16]$} \\
\hline Ipomea & Convolvulaceae & $\begin{array}{c}\mathrm{Cd}, \mathrm{Cu}, \mathrm{Mn}, \\
\mathrm{Zn}\end{array}$ & {$[11]$} \\
\hline Lonicera japonica & Caprifoliaceae & $\mathrm{Cd}$ & {$[17]$} \\
\hline Saccharum officinarum & Poaceae & $\mathrm{Cu}, \mathrm{Cd}, \mathrm{Se}$, & {$[18]$} \\
\hline Sedum alferedii & Crassulaceae & $\mathrm{Pb}$ & \\
\hline Solanum nigrum & Solanaceae & $\mathrm{Cd}$ & {$[19]$} \\
\hline Thlaspi caerluescen & Brassicaceae & $\mathrm{Cd}, \mathrm{Zn}, \mathrm{Pb}$ & {$[20]$} \\
\hline Pteris vittata & Pteridaceae & $\mathrm{As}, \mathrm{Cr}$ & {$[22]$} \\
\hline
\end{tabular}

Phytoremediation is use of special type of plants to decontaminate soil or water by inactivating metals in the rhizosphere or translocating them in their above ground parts. These new techniques have several advantages such as cheap and aesthetically pleasing (no excavation require), efficient and a more environment friendly means of remediating metal polluted sites [23].

There are several categories of phytoremediation technologies so far recognized these includes-

1) Phytoextraction or phytoaccumulation: It is the process used by the plants to accumulate contaminants from soil into root and to above ground shoots and leaves ( 0.01 to $1 \%$ dry weight, depending on the metal). This technique yields a mass of plants and pollutants that must be transported for recycling. Usually, the shoot biomasses are harvested for proper disposal in special site or are burnt to recover the metal. Elsholtzia splendens, Alyssum bertolonii, Thlaspi caerulescens and Pteris vittata are known examples of hyperaccumulator plants for $\mathrm{Cu}, \mathrm{Ni}, \mathrm{Zn} / \mathrm{Cd}$ and As, respectively [24].

2) Phytodegradation or phytotransformation: It refers to the uptake of organic contaminants from soil, sediments, or water and, subsequently their transformation to more stable, less toxic or less mobile forms via the action of various enzymes produced by the plant tissues. Populus species and Myriophyllium spicatum are examples of plants that have these enzymatic systems [25].

3) Phytostimulation: It is the plant assist bioremediation wherein stimulation of microbial degradation takes place. The application of phytostimulation is limited to organic contaminants. The microbial community in the rhizosphere is heterogeneous due to variable spatial distribution of nutrients, however species of the genus Pseudomonas are the predominant organisms associated with roots [26].
4) Phytovolatilization: In the process of phytovolatilization plants are used to absorb the contaminants from the soil and transferred it to volatile forms and finally into the atmosphere through transpiration process. In laboratory experiments, tobacco ( $N$. tabacum) and a small model plant (Arabidopsis thaliana) that had been genetically modified to include a gene for mercuric reductase converted ionic mercury to the less toxic metallic mercury $(\mathrm{Hg}(0)$ and volatilized it. This technique can also be used for organic compounds.

5) Rhizofiltration: Rhizofiltration involves the decontamination of polluted waters and sewage by adsorbing or up taking roots of plants. Rhizofiltration is similar to phytoextraction, but the plants are used primarily to address contaminated ground water rather than soil. The plants to be used for cleanup are raised in greenhouses with their roots in water rather than in soil. Many plants such as sunflower, Indian mustard, tobacco, rye, spinach, and corn are able to remove lead from water.

6) Phytostabilization: It is the technique in which plants reduce the mobility and migration of contaminants and contaminated soil through absorption and precipitation by plants, thus reducing their bio availability. It is very effective when rapid immobilization is needed to preserve ground and surface waters. This process reduces the mobility of the contaminant and prevents migration to the ground water or air, and it reduces bioavailability for entry into the food chain. Species of genera Haumaniastrum, Eragrostis, Ascolepis, Gladiolus and Alyssum are examples of plants cultivated for this purpose.

7) There are some other strategies, which are considered as the categories of phytoremediation by some authors, but actually, they are mixed techniques or variations of the above mentioned strategies. These include: Hydraulic barriers, constructed wetlands, phytodesalination etc.

\section{Drawback of phytoremediation}

Phytoremediation technologies offer several advantages such as more cost-effective, more environmentally friendly, and applicable to a wide range of toxic metals and more aesthetically pleasing method. On the other hand, phytoremediation presents some drawbacks which includes: (i) The presence of multiple types of heavy metals and organic contaminants may pose a challenge, (ii) climatic and hydrological conditions may limit the growth of plants utilized for the remediation purposes (iii) it is a lengthy process, thus it may take several years or longer to remediate a site and it is only applicable to surface soils, (iv) harvested plants biomass may acts as hazardous waste and needs proper disposal, (v) introduction of non-native species may affect the indigenous biodiversity, (vi) the contaminants may still enter the food chain through animals that eat plant material containing pollutants hence risk of food chain contamination in case of mismanagement and lack of proper care. To overcome the possible drawbacks of phytoremediation technology, the genetic engineering may be a suitable approach which may help the plants to develop resistance against abiotic as well as to combat higher concentration of toxic metals. 


\section{International Journal of Science and Research (IJSR) \\ ISSN (Online): 2319-7064}

Index Copernicus Value (2013): 6.14 | Impact Factor (2014): 5.611

\section{Concluding Remark}

Phytoremediation is a promising green technology that can be used to remediate heavy metal contaminated soils. There are several technical impairments, which needs to be come up to. Many new hyperaccumulator plant species that have remediative abilities need to be discovered and identified, especially the plants that can contribute to social and economic development of local population, such as industrial species. The understanding of plants regarding metal uptake process and proper biomass disposal is still to be unveiled. Further, research is required to develop the plants with high growth rate, high biomass, improved metal uptake, translocation and tolerance by using genetic engineering for the effective phytoremediation. The complexity of factors that control the efficiency of this technique, such as soils properties, plant species and climatic conditions, fact that more researches need to be conducted.

\section{Acknowledgements}

We are very grateful to Department of Botany, University of Allahabad, Allahabad for providing necessary lab facilities. The author Dr. Anita Singh is thankful to the Science \& Engineering Research Board (SERB), for providing fellowship under Start Up Research Grant (SB/YS/LS228/2013) as a DST-Young scientist.

\section{References}

[1] Dushenkov, S. (2003). Trends in phytoremediation of radionuclides. Plant and Soil 249: 167-175.

[2] Rajakaruna, N. and Kathleen, M. (2006). Tompkins and Peter G. Pavicevic Phytoremediation: an affordable green technology for the clean-up of metalcontaminated sites in sri lanka. Cey. Journal of Science. 35 (1), 25-39.

[3] Bridge, G. (2004). Contested terrain: mining and the environment. Annual Review of Environmental Research. 29, 205-259.

[4] Chaney, R.L., Angle, J.S., McIntosh, M.S., Reeves, R.D., Li, Y.M., Brewer, E.P., Chen, K.U., Roseberg, R., Perner, H., Synkowski, E.C., Broadhurst, C.L., Wang, S. and Baker, A.J.M. (2005). Using hyperaccumulator plants to phytoextract soil $\mathrm{Ni}$ and $\mathrm{Cd}, \mathrm{Z}$. Nature forsch. 60, 190-198.

[5] Garbisu, C., Alkorta, I. and Epelde, L. (2010). Heavy metal phytoremediation: microbial properties as bioindicators of soil health. Science Topics. Retrieved December 31, 2010.

[6] Chandra, R., Saxena, G. and Kumar, V (2015). Phytoremediation of environmental pollutants: An ecosustainable green technology to environmental management. In: Advances in biodegradation nd bioremediation of industrial waste (Eds. Ram Chandra), CRC press, Boca Raton, Florida (USA), 1-30.

[7] Beyersmann, D. and Hartwig, A. (2008) Carcinogenic metal compounds: recent insight into molecular and cellular mechanisms. Archive of Toxicology. 82, 493512 .
[8] Zhen-Guo, S., Xian-Dong, L., Chun-Chun, W., HuaiMan, Ch. and Hong, Ch. (2002). Journal of Environmental Quality. 31, 893-1900.

[9] Sarma, H. (2011). Metal hyperaccumulation in plants: a review focusing on phytoremediation technology. Journal of Environvental Science and Technology. 4, 118-138.

[10]Barman, S.C., Sahu, R.K., Bhargava, S.K. and Chaterje, C. (2000). Distribution of heavy metals in wheat, mustard and weed grown in field irrigated with industrial. Bulletin of Environmental Contamination and Toxicology 64, 489-496.

[11] Gupta, S., Nayek, S., Saha, R.N. and Satpati, S. (2008). Assessment of heavy metal accumulation in macrophyte, agricultural soil and crop plants adjacent to discharge zone of sponge iron factory. Environmental Geology. 55, 731-739.

[12] Kramer, U. (2010). Metal hyperaccumulation in plants. Annual Review of Plant Biology. 61, 517-534.

[13]Li, Y., Dhankher, O.P., Carreira, L., Lee, D., Chen, A., Schroeder, J.I., Balish, R.S and Meagher, R.B. (2004). Overexpression of phytochelatins synthase in Arabidopsis leads to enhanced arsenic tolerance and cadmium hypersensitivity. Plant Cell Physiology. 45(12), 1787-1797.

[14] Tang, Y.T., Qiu, R.L., Zeng, X.W., Ying, R.R., Yu, F.M. and Zhou, X.Y. (2009). Lead, zinc, cadmium hyperaccumulation and growth stimulation in Arabis paniculata. Franch Environmental and Experimental Botany. 66, 126-134.

[15] Selvam, A. and Wong, J.W. (2008). Phytochelatin systhesis and cadmium uptake of Brassica napus. Environmental Technology. 29, 765-773.

[16] Rohan, J.D., Varun, M., Masih, J. and Paul, M.S. (2010). Identification of Calotropis procera L. as a potential phytoaccumulator of heavy metal from contaminated soils in Urban North Central India. Journal of Hazardous Material. 84, 457-464.

[17] Liu, Z.L., Chen, W. and He, X.Y. (2011). Cadmiuminduced changes in growth and antioxidative mechanisms of a medicine plant (Lonicera japonica Thunb.). Journal of Medicinal Plants Research. 5, 1411417.

[18] Yan, Z. and Zia, H. (2010). Evaluation of the phytoremediation potential of sugarcane for metalcontaminated soils. In: Bioinformatics and biomedical engineering (iCBBE), $20104^{\text {th }}$ international conference, $1-4$.

[19] Deng, D.M., Shu, W.S., Zhang, J., Zou, H.L., Ye, Z.H., Wong, M.H. and Lin, Z. (2007) Zinc and cadmium accumulation and tolerance in populations of Sedum alfredii. Environmental Pollution. 147, 381-386.

[20] Chen, L., Li, S.L.X., Yong, Wan. Y., Chen, J. and Liu, C. (2014). Interaction of Cd-hyperaccumulator Solanum nigrum L. and functional endophyte Pseudomonas sp. Lk9 on soil heavy metals uptake. Soil Biology \& Biochemistry 68, 300-308.

[21] Gustin, J.L., Loureiro, M.E., Kim, D., Na, G., Tikhonova, M. and Salt, D.E. (2009). MTP1-dependent $\mathrm{Zn}$ sequestration into shoot vacuoles suggests dual roles in $\mathrm{Zn}$ tolerance and accumulation in $\mathrm{Zn}$ hyperaccumulating plants. Plant Journal. 57, 11161127. 


\section{International Journal of Science and Research (IJSR) \\ ISSN (Online): 2319-7064}

Index Copernicus Value (2013): 6.14 | Impact Factor (2014): 5.611

[22] Oliveira, L.M., Ma, L.Q., Santos, J.A.G., Guilherme, L.R.G. and Lessl, J.T. (2014). Effects of arsenate, chromate, and sulfate on arsenic and chromium uptake and translocation by arsenic hyperaccumulator Pteris vittata L.. Environmental Pollution. 184, 187-192.

[23]Lone, M.I., He, Z., Stoffella, P.J. and Yang, X. (2008). Phytoremediation of heavy metal polluted soils and water: progress and perspectives. Journal of Zhejiang University of Science B. 9, 210-220.

[24] Prasad, M.N.V. (2004). Phytoremediation of metals and radionuclides in the environment: the case for natural hyperaccumulators, metal transporters, soil-amending chelators and transgenic plants. In: Prasad MNV. (Eds.) Heavy metal stress in plants: from biomolecules to ecosystems, Second Edition. Berlin: Springer, 345-391.

[25] Rylott, E.L. and Bruce, N.C. (2008). Plants disarm soil: engineering plants for the phytoremediation of explosives. Trends in Biotechnology. 27(2), 73-81.

[26]Ali, H., Khan, E. and Sajad, M.A. (2013). Phytoremediation of heavy metals - Concepts and applications. Chemosphere. 91, 869-881. 